\title{
The Determinants of Bank Risk Taking: Evidence From Jordan
}

\author{
Ali Awartany ${ }^{1} \&$ Khaled Alzubi ${ }^{1}$ \\ ${ }^{1}$ Department of Banking and Financial Sciences, The Hashemite University, Jordan \\ Correspondence: Khaled Alzubi, Department of Banking and Financial Sciences, The Hashemite University, Jordan.
}

Received: August 8, 2020

doi:10.5430/ijfr.v11n6p100

Accepted: September 14, 2020

Online Published: November 30, 2020

URL: https://doi.org/10.5430/ijfr.v11n6p100

\begin{abstract}
This study examines the determinants of bank risk taking for a sample of 15 Jordanian banks, according to Basel I and Basel II standards for capital regulation and by testing the relationship between bank risk taking and banks financial information using multiple linear regression analysis. The study found that most Jordanian banks committed to capital adequacy ratio regulations which decrease the bank risk taking, Bank Risk Taking (RSK) was found to be adversely affected by Capital Adequacy Ratio (CAR), The Franchise value (FRN) has a negative effect on bank risk taking (RSK), The Stable Shareholder (HLD) variable has a significant positive effect on Bank Risk Taking (RSK). The squared value of Stable Shareholders (HLD_SQR) has a significant negative effect on Bank Risk Taking (RSK).
\end{abstract}

Keywords: bank risk taking, capital adequacy ratio, stable shareholders, franchise value, log of total assets, frequency

JEL classification: G21, G32, G28, C33

\section{Introduction}

The banking industry has changed radically over the past years; the changes include its size growth and geographic reach, diversity of activities, new instruments and services development, and the usage of advanced technology. These changes increased risk profiles of many banking organizations. Because of that, banks are motivated to use complex financial tools to analyze and manage the risks in order to minimize any negative effects, such as securitizations and credit derivatives. Banking sector is different than other sectors in the economy because it manages many types of risks jointly, that is due to the risks involved in its operations; including operational risk, concentration risk, interest rate risk, liquidity risk, market risk, and credit risk.

Risk-taking is crucial issue that have received considerable attention in finance literature and become one of the most important topics lately, especially after the international crisis its refers to the tendency to behave in a way that have the potential to cause undesirable consequences or financial loss, but might also at the same time provide an opportunity for rewarding outcome that can be perceived as positive. So, it is very important and critical to determine the factors that have an impact on bank risk taking in Jordan; the topic of this paper. To minimize the financial crisis impact and establish a solid banking industry, the central bank of Jordan requested banks to apply Basel II implications, which mainly concentrate on setting up rigorous capital and risk management requirements, developed to ensure that banks maintain appropriate capital to the risk expose themselves to through its operations which include lending and investment activities.

(Zong-yi et al., 2008) states that to ensure the importance of capital adequacy and Basel II as an international regulation, the international similarities of the capital adequacy regulations and standards which has become the primary measure in this topic around the world, there have been a different opinions in theoretical literatures and supervisory practices sides concerning how banks modify the total amount and the distribution of their capital and risk weighted assets under the regulations related to capital adequacy, and to assess if complying with those regulations could end up with decreasing the risks of the financial institutions effectively.

It is important to determine the effect of stable shareholders on risk taking for Jordanian banks. (Konishi et al., 2004), stated that the stability of shareholders may have a negative or positive effect on risk taking for banks. The negative effect appears when the investors of the bank become less risk averse than managers, the managers goal is to protect the bank human capital. If a bank manager also has shares in the bank, it motivates them to protect bank financial capital. The positive effect of stable shareholders on bank risk taking occurs when a bank managers and shareholders' preferences are aligned. Meaning that managers may have motivations to take risk in order to increase the value of 
the shareholders' wealth.

(Weisbrod et al., 1992) argued that the provision of current assets and payments services to banks' customers is known as franchise value. If the demand for bank services increase the franchise value of the bank will increase. (Demsetz et al., 1996), argued that a distribution and number of bank branches could give it an advantage in dealing with customers which looking for a full banking services at one local branch. recently, the advantage of the branches location, the coverage and variety of the services provided by the branch has been clearly identified. Moreover, as in any other sector, some banks are more efficient than others due to many reasons. The well managed banks derive franchise value from their ability to provide the services with lower prices than the competitors. They also argued that the franchise value is significant in banking as it supports to mitigate the "moral hazard problem" related to federal safety net.

This study investigated empirically the determinants of Bank risk taking for the period from 1999 to 2009 in 15 Jordanian bank. The study hypotheses found a significant negative relationship between Bank risk taking (RSK) as a dependent variable and Capital Adequacy Ratio (CAR) and squared value of Stable Shareholders (HLD_SQR) and The Franchise value (FRN) as independent variables, the study also found that the Stable Shareholder (HLD) variable has a significant positive effect on Bank Risk Taking (RSK).

\section{Literature Review}

\section{Capital Adequacy Ratio (CAR) \& Government Regulations}

(Konishi et al., 2004) empirically examined the determinants of banks risk taking in Japan. Panel data of the Japanese regional banks for the period from 1990 to 1999 was used, it was concluded that the adaptation of the capital adequacy ratio (CAR) minimized the risk taking at banks, (Zong-yi et al., 2008), empirically found the same negative relationship, between implementation of capital standards and bank risk taking in China. It was found that the change in capital is significantly negative with risk taking. (Leonard et al., 1998), investigated the changes in the risk-taking behavior of New York State chartered saving banks resulting from regulatory changes, they found that increasing regulatory scrutiny limiting the risk-taking of saving banks after 1988. (Buch et al., 2008), showed that the absence of banks' supervision could give banks the opportunity to shift risk from themselves to supervisors. The study also found that the monitoring and controlling of the shareholders" countries has an impact on the changes in post-merger total risk. An acquirer from a country with solid supervision reduces total risk after a cross-border merger. However, total risk increases when the target bank is located in a country with relatively strong supervision.

Some studies argued that there is a positive relationship between capital adequacy ratio and other regulations and bank risk taking as in (Blum, 1999) found a positive relationship between capital adequacy regulations and bank risk taking, in addition to the negative effect of rents on risk taking of banks. (Godlewski, 2005) investigated the relationship between the capital of banks and credit risk behaviors in emerging economies. The study showed an evidence on the role of the institutional, regulatory and legal areas in the bank capitalization and credit risk levels. (Lin et al., 2005) implemented insolvency-risk (IR) index as an indicator to measure the insolvency risk in Taiwan's banking industry for the period from 1993 to 2000, to investigate the relationship between capital adequacy (CA) in assessing on IR and financial performances. The results of this study showed a positive relationship between Insolvency Risk index and the Capital Adequacy, and that a significantly positive relationship exists between Capital Adequacy and financial performances. (Laeven et al., 2009) concluded that the relationship between bank risk, deposit insurance policies, capital regulations, and restrictions on bank products and services depend critically on the ownership structure of the bank, such as the actual sign of the effect of regulatory framework on risk changes based on the ownership concentration. (Laeven et al., 2006) argued that capital requirements and official supervisory don't affect bank risk taking. (Kim et al., 1998) investigated the role of the regulations which related to bank capital in the control of the bank risks. The study found that the use of simple capital ratios in regulation has no effect on mitigating the insolvency risk of the banks.

\section{Stable Shareholders and Concentration of the Ownership}

(Konishi et al., 2004) found that banks boards inclusion of some retired government officials has no significant effect on bank risk, and that there is a nonlinear relationship between stable shareholders' ownership and bank risk; and the ownership by stable shareholders reduces the risk in the initial stages, then increases as the asset substitution effect dominates the effect of managerial entrenchment on bank risk. (Iannotta et al., 2007) proved that there is a negative relationship between ownership concentration and insolvency risk. They analyzed a sample of 181 large banks from 15 European countries for the period from 1999 to 2004.

Many studies argue that the relationship between many variables related to stocks ownership concentration, such as stocks owned by hired managers, strong board, greater stockholder control, and stronger creditor rights as an 
independent variables and bank risk taking as a dependent variable is positive. (Sullivan et al., 2007) The empirical results of the study are concentrated in: the ownership of managers has a negative impact on the earnings, the risk of the managers reduced when the board of directors or board members has a motivation to monitor bank management has his wealth concentrated in the bank, and that the managers stock ownership increases the total risk of the bank. (Pathan, 2009) showed that the existing of strong bank board has a positive impact on bank risk-taking. In the other side, CEO power has a negative impact on bank risk-taking. The researcher used a sample of 212 US large banks for the period from 1997 to 2004, with 1534 observations. (Marco et al., 2008) analyzed the determinants of risk-taking in Spanish financial intermediaries, the study tested many hypotheses related to these issues with a model of dynamic panel data, the study covers the years from 1993 to 2000 for Spanish banks (commercial and saving), the researchers also analyzed the impact of the different ownership structures and the size of the bank on the risk behavior. (Houston et al., 2010) studied a sample of approximately 2400 banks in 69 different countries. The study found that stronger creditor rights has a significant positive impact on bank risk taking. (Laeven et al., 2009) also conducted an empirical analysis of theories related to risk taking by banks, ownership structures and local bank regulations. The study focused on conflicts between bank owners and managers over risk, and showed that bank risk taking changes positively with the power of owners within each bank corporate governance structure.

\section{Franchise Value}

The effect of franchise value on bank risk taking is stated to have a negative relationship in most studies. (Konishi et al., 2004) found that the negative change of franchise value increases bank risk, which reflects the negative relationship between franchise value and bank risk taking. (Jiménez et al., 2007) study used a unique dataset for the Spanish banking system, it was found a negative relationship between the power of loan market and bank risk. This result provides evidence in favor of the franchise value negative relation to the bank risk taking. (Weisbrod et al., 1992) combined both the increase of wholesale banks taken risk in the United States and the reduction in earnings at Japanese wholesale banks franchise value reduction of wholesale banking. (Demsetz et al 1996) explored the relationship between franchise value and risk taking the researchers covers the years from 1986 to 1994. The study extended Keeley's analysis by testing the effect of franchise value on a bank risk using multiple measures. The study found a negative relationship between franchise value and a stock return volatility as a risk indicator.

\section{Bank Risk Taking}

(Jeitschko et al., 2005), examined four different assumptions on the risk return profiles and derived conditions under which bank's risk increases or decreases with capitalization. The study used the assumption that agents deposit insurers, shareholders and managers all have an impact on bank's risk levels. (Jokipii et al., 2010) built an unbalanced panel for the United States Bank Holding Company (BHC) and a commercial bank balance-sheet data for the period which covers the years from 1986 to 2008. The study tested the relationship between short-term capital buffer and portfolio risk modifications. Estimations indicate that the relationship over the period sample is a positive two-way relationship. (Lepetit et al., 2008) investigated the relationship between bank risk and the diversifications of products in the dynamic structure of the European banking industry for the years over 1996 to 2002, the study showed that banks which focus on non-interest income business present higher risk and higher insolvency risk than banks which mainly focus on loans. (Lindquist et al., 2004) used bank-level panel data from Norway to study the important hypotheses which related to the determination of the buffer capital. The study concluded a negative or non-significant risk effect, which suggests that using a more risk-sensitive capital regulation (Basel II) is likely to affect Norwegian banks. (Repullo et al., 2004) presented a dynamic model for banks imperfect competition, where banks can invest in a stable or a gambling asset. The study showed that if intermediation margins are small, the bank's franchise values will be small and in the absence of regulation only a gambling equilibrium will exist. (Cebenoyan et al., 2004) tested active management of bank credit risk exposure through the loan sales market impact on capital structure, profits, lending and risk. The study found that banks that rebalance their loan portfolio exposures by both buying and selling loans, hold less capital than other banks. (Murphy et al., 1997) examined the experience of Massachusetts saving banks. The study analyzed a panel of 115 saving banks for the years from 1985 to 1993. It found that the cyclical decline in property values resulted in a decline in the quality of loan credit portfolios with a substantially higher impact on those saving banks that converted from mutual to stock status. (Niinimaki et al., 2003) considered the effect of both competition and deposit insurance on banks' risk taking when bank risk is unclear to depositors. The study found that the degree of risk taking depends on the structure and side of the market in which competition takes place. If the bank is a monopoly, or banks are competing in loan market only, then deposit insurance has no impact on risk taking. The study found that introducing deposit insurance increases risk taking if banks are competing for deposits. Then, deposit rates become excessively high, which forcing banks to take very high risks. 
Table 1. Main results in the literature review related to bank's risk taking

\begin{tabular}{ccc}
\hline Study & Variables & Relationship \\
\hline Konishi et al., 2004 & Capital Adequacy Ratio \& Risk & Negative \\
& Stable Shareholders \& Risk & Non-Linear \\
Zong-yi et al., 2008 & Franchise Value \& Risk & Negative \\
Sullivan al., 2007 & Capital \& Risk & Negative \\
Pathan 2009 & Stock Ownership by Managers \& Risk & Positive \\
& Strong Bank Boards \& Risk & Positive \\
Marco et al., 2008 & CEO power \& Risk & Positive \\
Jokipii et al., 2010 & Greater Stockholder Control \& Risk & Positive \\
& Short-Term Capital Buffer \& Portfolio Risk Adjustments & Two-Way \\
Lepetit et al., 2008 & & Positive \\
Houston et al., 2010 & Banks focus Into Non-Interest Income Activities \& Risk & Positive \\
& Stronger Creditor Rights \& Risk & Positive \\
Blum 1999 & Information Sharing Among Creditors \& Risk & Negative \\
Buch et al., 2008 & Capital Adequacy Rules \& Risk & Positive \\
Cebenoyan et al., 2004 & Countries With Strong Supervision \& Risk & Positive \\
Lin et al., 2005 & Banks Active in the Loan Sales Market \& Risk & Negative \\
& Capital Adequacy \& Insolvency-Risk & Positive \\
Godlewski 2005 & Financial Performances \& Insolvency-Risk & Negative \\
Laeven et al., 2006 & Regulatory Environment \& Credit Risk-Taking & Positive \\
& Owners with Cash-Flow Rights \& Risk & Positive \\
Leonard et al., 1998 & Capital Requirements and Official Supervisory \& Risk & No Effect \\
Jiménez et al., 2007 & Regulations That Promote Loan Diversification \& Risk & Negative \\
Weisbrod et al., 1992 & Increased Regulatory Scrutiny \& Risk & Negative \\
Demsetz et al., 1996 & Loan Market Power \& Risk & Negative \\
\hline & Franchise Value \& RSK & Negative \\
& Franchise Value \& RSK & Negative \\
& Franchise \& “All-In” Measure of Risk & Negative \\
\hline
\end{tabular}

The study aims to test bank risk taking factors in Jordanian banks as there are no previous studies cover this area for Jordanian banks, the researchers used the literature review to determine the variables that should be used as a determinants of bank risk taking for the study model, this study will enhance the field as it uses enhanced and more comprehensive model which combine more than one study variables.

\section{The Model}

According to the previous literature reviews, this paper will use panel data for Jordanian banks to test the multiple regression model for bank risk taking, as a dependent variable, and capital adequacy ratio, shares owned by stable shareholders and franchise value, as independent variables, using total assets and frequency as control variables in order to capture the size effect between banks in the regression model. The developed regression model is shown in the below equation:

$$
\text { RSKit }=\beta_{o}+B_{1} C A R i t+\beta 2 H L D i t+\beta 3 H L D^{2} i t+\beta 4 F R N i t+\beta 5 L T O A i t+\beta 6 F R Q i t+\varepsilon i t
$$
Where:

RSKit : Banks Risk Taking for bank i at time $\mathrm{t}$

CARit : Capital Adequacy Ratio for bank i at time $\mathrm{t}$

HLDit : Holdings for bank i at time $\mathrm{t}$

$H L D^{2} i t$ : The Square value of holdings for bank i at time $\mathrm{t}$

FRNit : Franchise Value for bank $\mathrm{i}$ at time $\mathrm{t}$

LTOAit : The Log value of Total Assets for bank i at time $\mathrm{t}$ 


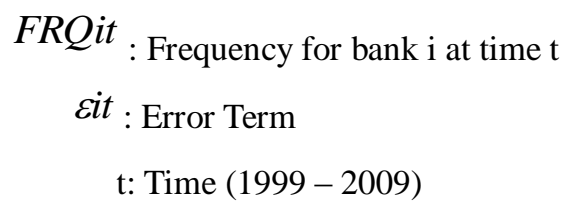

\section{Bank Risk Taking}

(Zong-yi et al., 2008), (Delis et al., 2010) measured the risk-taking behavior of banks using primarily two ratios, which are the ratio of risky assets to total assets and the ratio of Non-Performing loans to total loans. The researchers mentioned that bank risky assets cover all bank assets except cash, government securities (at market value) and balances at other banks. In general, risky assets can be defined as any bank asset that might change in value due to changes in market conditions or changes in quality of credit at different pricing situations. In addition, they defined Non-Performing loans as an indicator for credit risk. Because a percentage of Non-Performing loans will result in losses for the bank, a high value of this ratio is associated with higher credit risk. (Demsetz et al., 1996) assumed that the risk can be identified and calculated based on the changes of bank's stock returns over time, by calculating the standard deviation of weekly stock returns for each bank in each year. (Laeven et al., 2006) (Laeven et al., 2009) and (Houston et al., 2010) measured bank risk using the Z-score, which equals the return on assets plus the capital asset ratio divided by the standard deviation of asset returns. Because the Z-score is highly skewed, the natural logarithm of the Z-score was used as the risk measure. The Z-score measures the distance from insolvency, which is a state in which losses surmount equity.

(Lin et al., 2005) and (Marco et al., 2008) used an index to measure bank risk taking, this index is called Insolvency Risk Index, which mainly depends on the bank's security. The numerator of the index is the return on assets $\sigma$ (ROA) or standard deviation, and the denominator is the return on assets plus shareholders' equity ratio. Under the notion of a fixed return on assets and shareholders' equity, when there is high fluctuation with return on assets, the insolvency risk index will increase. On the other hand, under the notion of a fixed standard of profit fluctuation should return on assets increase, the insolvency risk index will decrease. In this paper, the researchers will use the Insolvency Risk Index as a measure for Jordanian banks' risk taking, since it has been used in many previous studies and it is internationally considered as a measure of banks' risk taking, in addition to that, Insolvency Risk Index (IR) components have an available data for the period of the study.

$$
I R=\frac{\sigma R O A}{R O A+\frac{C}{T O A}}
$$

Where:

$I R:$ Insolvency risk index.

OROA : Standard deviation of assets return over the period 1999-2009.

$$
\begin{gathered}
R O A \text { : Return on assets. } \\
C \text { : Total capital. } \\
T O A \text { : Total assets. }
\end{gathered}
$$

\section{Capital Adequacy Ratio}

(Hasan, 2002) commented on banks' capital that it mainly provides a cushion against solvency. If bank losses exceed bank capital, the bank will become capital insolvent, high bank capital means high solvency. According to (Zong-yi et al., 2008) the capital ratio (CAP) is the total capital (Tier 1 + Tier 2) to total risk-weighted assets, using Capital Adequacy Ratio calculated by banks as per the capital standards issued in 2004. In this study, the researchers will use the capital adequacy ratio according to leverage ratio, Basel I accord and Basel II accord to be compatible with using these three measurements by Jordanian banks in the following way:

- The leverage ratio will be used for the period from 1999 to 2001, because of that Capital Adequacy Ratio (CAR) was not used in this period (not exist for Jordanian banks) the researchers will use the leverage ratio as an index for CAR. 
- The Basel I capital adequacy ratio will be used for the period from 2002 to 2007, the researchers will use the calculated and declared Capital Adequacy Ratio by Jordanian banks.

- The Basel II capital adequacy ratio will be used for the period from 2008 to 2009, the researchers will use the calculated and declared Capital Adequacy Ratio by Jordanian banks.

\section{Stable Shareholders}

This variable measures stable shareholders whom do not engage in stock trading at the short term. (Konishi et al., 2004) used this variable in their regression model and defined the variable as: The percentage of the bank's shares owned by stable shareholders. (Houston et al., 2010) states that stockholders and creditors usually have different interests, stockholders have more incentives for risk taking, but rational creditors will consider these incentives when deciding the conditions under which to grant credit. Consequently, it is often mandatory for borrowers to find ways to credibly commit that they will not engage in excessive risk taking. To the level that the strength of creditor rights and the level of information sharing affects the contracting environment, they are also likely to have important influence on creditors' ex-ante incentives as well as the recovery rates in the event of a default. The levels of sharing the information and of creditors rights are also likely have an impact on the overall level of credit. (Laeven et al., 2006) assumed that bank risk is systematically higher in banks that have large owners with substantial cash flow rights.

In addition to the stable shareholders' variable this paper added the squared values of stable shareholder variable to the model to determine the effect of holdings on bank risk taking if it is linear or quadratic.

\section{Franchise Value}

Franchise value as measured by (Konishi et al., 2004) is the total of the market value of equity plus the book value of liabilities divided by the book value of assets. (Demsetz et al., 1996) defined the franchise value as the present value of the stream of earnings that a company is expected to earn as a going concern makes the supervisor's job easier by reducing banks' motivations to take risk. And they argued that in banking the sources of franchise value include access to markets protected from competition, valuable lending relationships, and efficiency. Franchise value can help reduce excessive risk taking because banks with high franchise value have much to lose if a risky business strategy leads to insolvency. (Demsetz et al., 1996), (Jonghe et al., 2008), and (Ren et al., 2006) used the franchise value as the value of the current and future profits that a bank is expected to earn as a going concern, they measured the franchise value by using the Tobin's $Q$ ratio which is proxied by the ratio of a bank's market value to its book value. (Demsetz et al., 1996) argued that one way to calculate franchise value is to look at the difference between a firm's market value and its replacement cost. (Marcus, 1984) developed option-pricing models that shows how franchise value can induce risk averting, which is known as Franchise Value Theory (FVT). This theory predicts negative effect of franchise value on firm risk-taking. (Ren et al., 2006) the economic worth of a firm includes the value of both tangible and intangible assets. They argued that the franchise value represents a firm's intangible assets, which is the value of the firm above and beyond the value of its tangible assets.

The researchers will use the "Tobin's Q" ratio as a measure for the franchise value because it is an internationally acceptable measurement and it the most common used measurement for franchise value, and this measurement has an available data for the period of the study. In this study as in (Ren et al., 2006) and (Konishi et al., 2004) studies, the researcher will use the "Tobin's Q" ratio without using the Goodwill because it is hard to measure it for the Jordanian banks in the study period, so the equation will be divided only by the book value of assets as shown below.

$$
Q=\frac{E+L}{(A-\text { Goodwill })}
$$

Where:

$$
\begin{aligned}
& Q \text { : Tobin's Q } \\
& E \text { : Market Value of Equity } \\
& L: \text { Book Value of Liabilities }
\end{aligned}
$$


$A$ : Book Value of Tangible Assets

Total Assets

According to (Zong-yi et al., 2008) bank size may have an impact on investment opportunities of the bank, reputation and portfolio diversification, and on the bank's access to equity capital. (Iannotta et al., 2007) used the variable SIZE as the log of Total Assets, to control the bank size in the study's model. It was pointed out that larger banks have better opportunities to diverse the risk, in addition to funding lower cost than smaller one. Also, larger banks should show relatively higher levels of net interest income. The study also debates that larger banks would benefit from an implicit guarantee that, other things equal, decreases their cost of funding and allows them to invest in riskier assets. (Zong-yi et al., 2008), used bank size as a control variable, because bank size may have an impact on bank's investment opportunity, reputation and portfolio diversification, and on the bank's access to equity capital. The study included the natural $\log$ of total assets to capture size effects. According to (Lin et al., 2005) bank operational size is taking the natural logarithm of total assets to understand the size of a sample bank, so it's used as an indicator to know whether it affected the bank's financial performance.

In this paper, the researchers added the variable Log of Total Assets to the regression model as a control variable in order to capture the banks size effect on risk taking.

\section{Frequency}

According to (Konishi et al., 2004) the frequency variable is measured by the average daily volume of shares divided by the total number of outstanding shares.

Table 2. Measurements of the model ratio

\begin{tabular}{|c|c|c|}
\hline Variable & Measurement & Sources \\
\hline Bank Risk Taking & $I R=\frac{\sigma R O A}{R O A+\frac{C}{T O A}}$ & $\begin{array}{l}\text { (Laeven et al., 2009) } \\
\quad \text { (Lin et al., 2005) } \\
\text { (Houston et al., 2010) }\end{array}$ \\
\hline Capital Adequacy Ratio & $\begin{array}{l}\text { - } 1999 \text { to 2001: leverage ratio } \\
\text { - } 2002 \text { to 2007: Basel I capital } \\
\text { adequacy ratio } \\
\text { - } 2008 \text { to 2009: Basel II capital } \\
\text { adequacy ratio }\end{array}$ & $\begin{array}{c}\text { (BIS, 2004) } \\
\text { (BIS, 2006) } \\
\text { (Zong-yi et al., 2008) } \\
\text { (Lin et al., 2005) }\end{array}$ \\
\hline Stable Shareholders & $\begin{array}{l}\text { The fraction of the bank's shares } \\
\text { owned by stable shareholders }\end{array}$ & $\begin{array}{l}\text { (Konishi et al., 2004) } \\
\text { (Laeven et al., 2006) }\end{array}$ \\
\hline $\begin{array}{l}\text { Squared Values of } \\
\text { Stable Shareholders }\end{array}$ & $\begin{array}{c}\text { Squared values of the fraction of the } \\
\text { bank's shares owned by stable } \\
\text { shareholders }\end{array}$ & $\begin{array}{c}\text { (Konishi et al., 2004) } \\
\text { (Laeven et al., 2006) }\end{array}$ \\
\hline Franchise Value & $Q=\frac{(E+L)}{(A-G o o d w i l l)}$ & $\begin{array}{l}\text { (Konishi et al., 2004) } \\
\text { (Demsetz et al., 1996) } \\
\text { (Jonghe et al., 2008) } \\
\text { (Ren et al., 2006) }\end{array}$ \\
\hline Log of Total Assets & The natural logarithm of total assets & $\begin{array}{l}\text { (Iannotta et al., 2007) } \\
\text { (Zong-yi et al., 2008) } \\
\text { (Lin et al., 2005) }\end{array}$ \\
\hline Frequency & $\begin{array}{l}\text { The average daily volume of shares } \\
\text { divided by the total number of } \\
\text { outstanding shares }\end{array}$ & (Konishi et al., 2004) \\
\hline
\end{tabular}




\section{Hypotheses}

The researchers expect a significant effect of the independent variables on banks' risk taking, according to the developed model, the research's hypotheses are:

Hypothesis 1: (H0) Capital adequacy ratio (CAR) is not negatively and not significantly affects the level of bank risk taking.

Hypothesis 2: (H0) The ownership by stable Shareholders (HLD_SQR) is not negatively and not significantly affects the level of bank risk taking.

Hypothesis 3: (H0) Franchise Values (FRN) is not negatively and not significantly affects the level of bank risk taking.

\section{Data and Empirical Analysis}

To estimate the multiple regression equation, the researchers have assigned three hypotheses, the population of this study consists of all working banks in Jordan that listed in ASE (Amman Stock Exchange). The selected sample contains all listed banks in ASE with available data for the period from 1999 to 2009, which are 15 banks. The study's observations are 165 because of the variables are collected in the annual base. The data was collected from the banks' annual reports, Amman Stock Exchange (ASE), and the Central Bank of Jordan. The researcher will apply a panel regression analysis on the collected data to test each independent variable.

The researchers used the Mean, Maximum, Minimum, Standard Deviation and Skewness for all variables (dependent \& independent) as a descriptive statistic for the data as shown in the below table, the descriptive statistic is made according to the year in order to find the trend of the feature of each variable in the study period.

As shown in the below graph the mean values of the variable (RSK) for the period 1999-2009 shows that the mean values were decreased before 2003. After 2003 it stayed between $4 \%$ and 5\% due to applying of Basel regulations in Jordan which is one of the reasons helped in banking system stability.

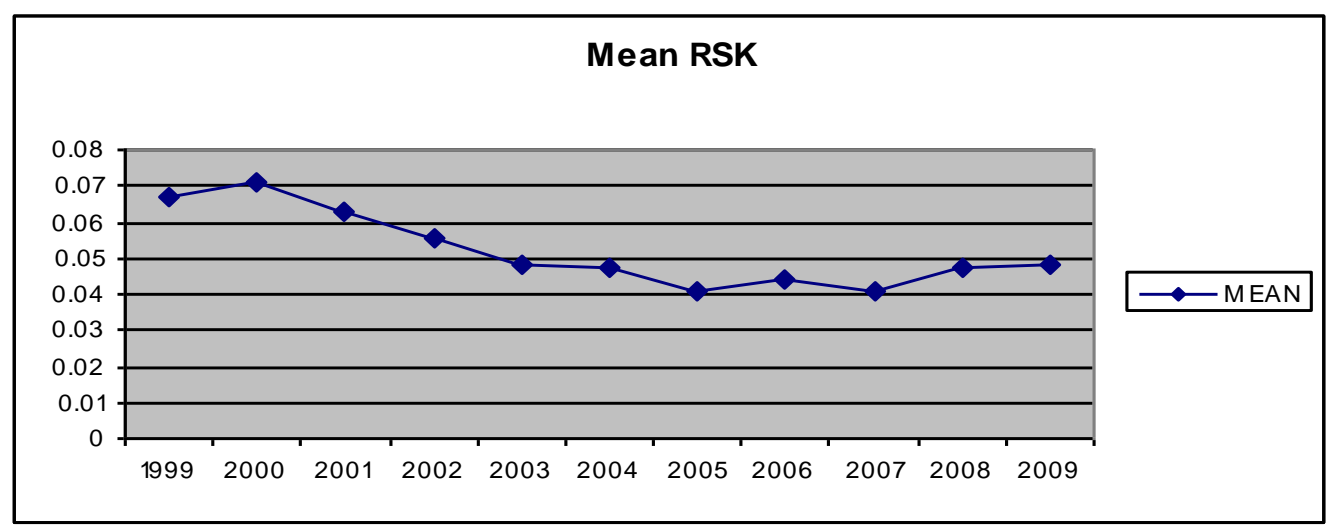

Figure 1. The change of mean value for variable RSK

The mean values of CAR were very low for the period 1999-2001 because of that the Basel regulations was not applied in Jordan for this period, after 2001 the CAR mean values become higher and more stable which always stayed between $18 \%$ and $21 \%$ which reflects the applying of Basel regulations. 


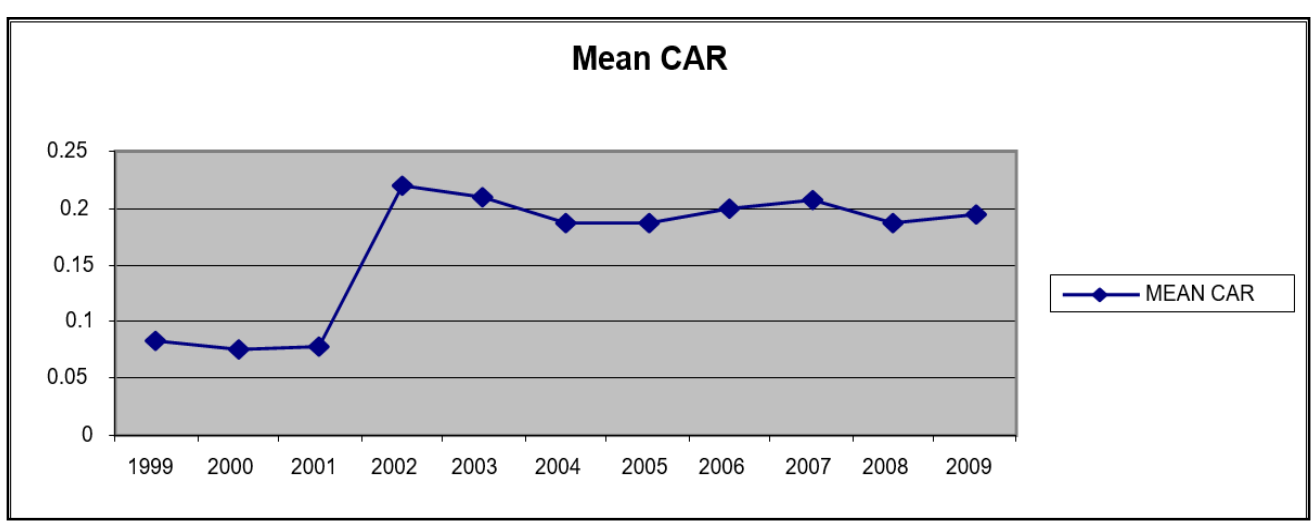

Figure 2. The change of mean value for variable CAR

As shown in the below chart the trend of the mean values of the variable HLD is increasing from year to year which reflects the increasing of the percentage of stable shareholders in Jordanian banks.

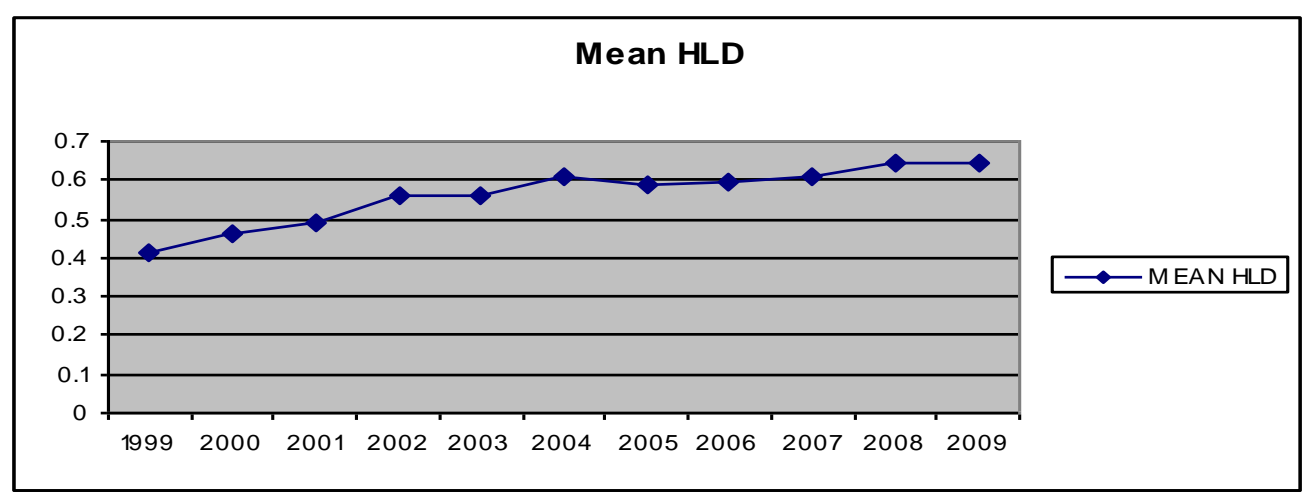

Figure 3. The change of mean value for variable HLD

For the variable HLD_SQR as in the variable HLD, the trend of the mean values of the variable HLD_SQR is increasing which reflects the increasing of the percentage of stable shareholders in Jordanian banks.

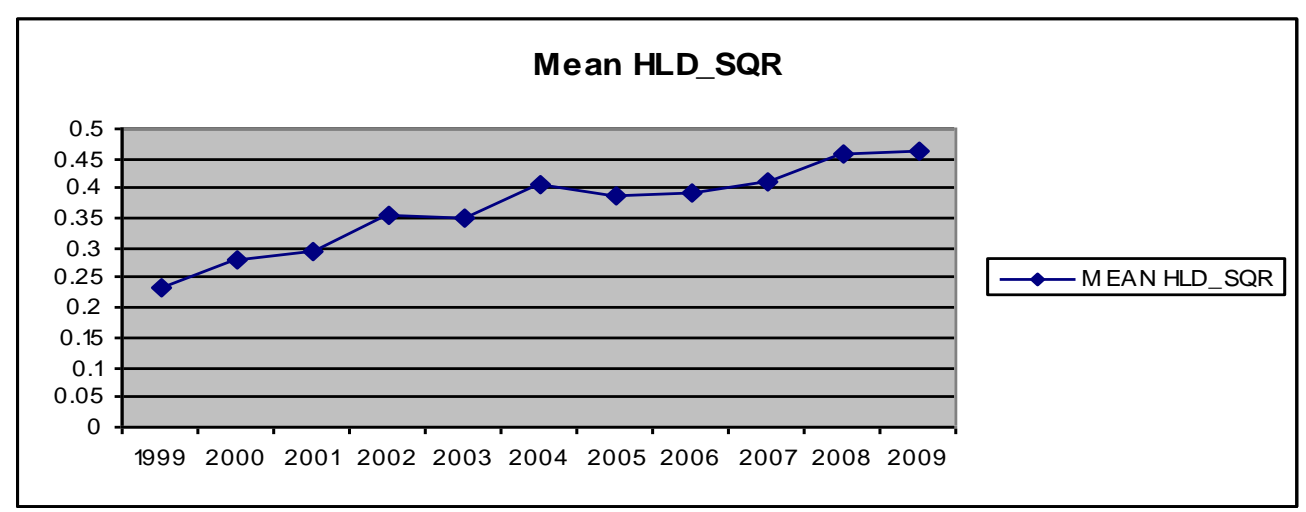

Figure 4. The change of mean value for variable HLD_SQR 
The mean values of franchise were increased from 2000-2004 due to the increasing in the stock prices and the profit of the Jordanian banks in this period, the decreasing of the mean values of FRN after 2004 is due to the increasing of the capital of banks which decreased the stock prices and due to the financial crisis which affect the stock prices and profit by decreased them.

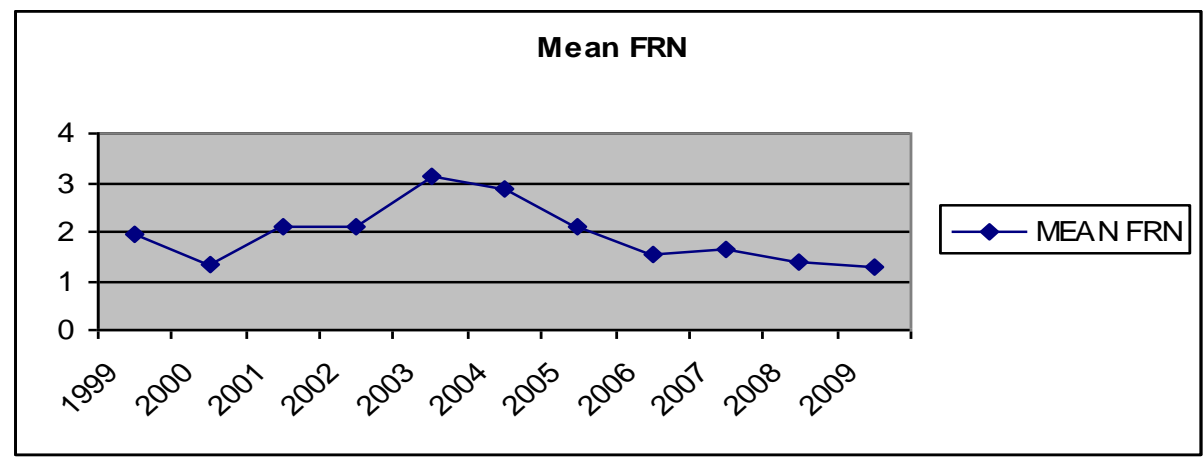

Figure 5. The change of mean value for variable FRN

The standard deviation of the variable LTOA is very stable; the stability in the standard deviation reflects that the changes happened in the most banks with each other.

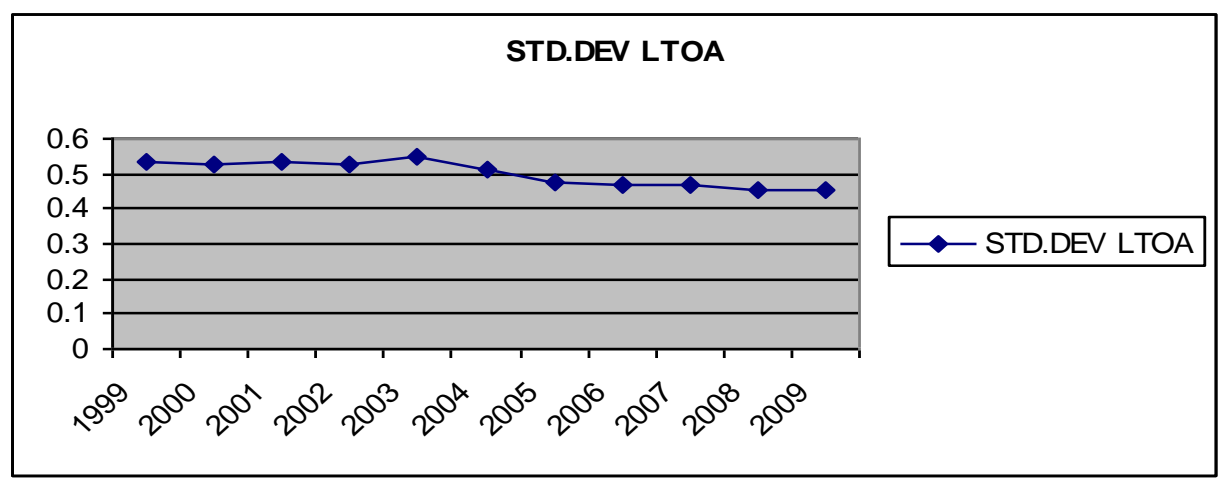

Figure 6. The change of standard deviation value for variable LTOA

Table 3. Descriptive statistic for Jordanian banks (1999 - 2009) according to the year

\begin{tabular}{|c|c|c|c|c|c|c|c|c|}
\hline Year & & RSK & CAR & HLD & HLD_SQR & FRN & LTOA & FRQ \\
\hline \multirow{5}{*}{1999} & MEAN & 0.0666 & 0.0829 & 0.4112 & 0.2345 & 1.9677 & 2.6541 & 0.000286 \\
\hline & MAX & 0.1160 & 0.1849 & 0.9700 & 0.9409 & 14.9111 & 4.1009 & 0.001043 \\
\hline & MIN & 0.0177 & 0.0070 & 0.1130 & 0.0128 & 0.9746 & 1.7859 & 0.000001 \\
\hline & STDEV & 0.0249 & 0.0560 & 0.2648 & 0.2813 & 3.5812 & 0.5366 & 0.000303 \\
\hline & SKEW & 0.0356 & 0.7095 & 0.9236 & 1.6328 & 3.8712 & 1.2488 & 1.415359 \\
\hline \multirow[t]{5}{*}{2000} & MEAN & 0.0711 & 0.0769 & 0.4630 & 0.2825 & 1.3408 & 2.7046 & 0.000201 \\
\hline & MAX & 0.1321 & 0.2360 & 0.9700 & 0.9409 & 5.9092 & 4.1413 & 0.001043 \\
\hline & MIN & 0.0143 & 0.0064 & 0.1157 & 0.0134 & 0.9654 & 1.8298 & 0.000014 \\
\hline & STDEV & 0.0292 & 0.0638 & 0.2702 & 0.2860 & 1.2643 & 0.5291 & 0.000272 \\
\hline & SKEW & -0.0337 & 1.6886 & 0.4482 & 1.1484 & 3.8678 & 1.2726 & 2.431549 \\
\hline \multirow[t]{3}{*}{2001} & MEAN & 0.0627 & 0.0773 & 0.4910 & 0.2967 & 2.0864 & 2.7533 & 0.000432 \\
\hline & MAX & 0.0892 & 0.2987 & 0.9700 & 0.9409 & 16.4932 & 4.1628 & 0.001269 \\
\hline & MIN & 0.0148 & 0.0060 & 0.2100 & 0.0441 & 0.9399 & 1.7274 & 0.000037 \\
\hline
\end{tabular}




\begin{tabular}{|c|c|c|c|c|c|c|c|c|}
\hline & STDEV & 0.0212 & 0.0719 & 0.2441 & 0.2777 & 3.9863 & 0.5361 & 0.000405 \\
\hline & SKEW & -1.3305 & 2.3625 & 0.6481 & 1.1913 & 3.8705 & 0.9379 & 0.984797 \\
\hline \multirow[t]{5}{*}{2002} & MEAN & 0.0553 & 0.2192 & 0.5582 & 0.3548 & 2.1145 & 2.7615 & 0.000439 \\
\hline & MAX & 0.0739 & 0.4600 & 0.9700 & 0.9409 & 16.9939 & 4.1677 & 0.001147 \\
\hline & MIN & 0.0036 & 0.0808 & 0.2410 & 0.0581 & 0.9490 & 1.8066 & 0.000035 \\
\hline & STDEV & 0.0210 & 0.0974 & 0.2152 & 0.2589 & 4.1171 & 0.5244 & 0.000389 \\
\hline & SKEW & -1.9031 & 1.0462 & 0.3567 & 0.9992 & 3.8704 & 1.1150 & 0.591864 \\
\hline \multirow[t]{5}{*}{2003} & MEAN & 0.0480 & 0.2094 & 0.5571 & 0.3506 & 3.1494 & 2.7721 & 0.001058 \\
\hline & MAX & 0.0691 & 0.3948 & 0.9700 & 0.9409 & 29.1567 & 4.1897 & 0.004285 \\
\hline & MIN & 0.0048 & 0.0964 & 0.2744 & 0.0753 & 1.0000 & 1.8250 & 0.000023 \\
\hline & STDEV & 0.0194 & 0.0909 & 0.2078 & 0.2571 & 7.2035 & 0.5485 & 0.001251 \\
\hline & SKEW & -1.2457 & 0.8281 & 0.5839 & 1.1530 & 3.8569 & 0.8987 & 1.869126 \\
\hline \multirow[t]{5}{*}{2004} & MEAN & 0.0473 & 0.1878 & 0.6080 & 0.4066 & 2.8957 & 2.8576 & 0.001176 \\
\hline & MAX & 0.0691 & 0.2800 & 0.9700 & 0.9409 & 24.1025 & 4.2257 & 0.003401 \\
\hline & MIN & 0.0082 & 0.1128 & 0.2927 & 0.0857 & 1.0000 & 2.0257 & 0.000053 \\
\hline & STDEV & 0.0184 & 0.0502 & 0.1989 & 0.2502 & 5.8739 & 0.5120 & 0.001097 \\
\hline & SKEW & -1.1107 & 0.4331 & 0.1496 & 0.6874 & 3.8566 & 1.2079 & 1.090920 \\
\hline \multirow[t]{5}{*}{2005} & MEAN & 0.0406 & 0.1869 & 0.5901 & 0.3896 & 2.1006 & 2.9645 & 0.001713 \\
\hline & MAX & 0.0575 & 0.2539 & 0.9700 & 0.9409 & 7.8895 & 4.2257 & 0.005691 \\
\hline & MIN & 0.0153 & 0.1210 & 0.2803 & 0.0786 & 1.0000 & 2.2250 & 0.000294 \\
\hline & STDEV & 0.0131 & 0.0422 & 0.2105 & 0.2576 & 1.7040 & 0.4764 & 0.001653 \\
\hline & SKEW & -0.5099 & 0.3305 & 0.1427 & 0.7111 & 3.1915 & 1.2132 & 1.684976 \\
\hline \multirow[t]{5}{*}{2006} & MEAN & 0.0441 & 0.2002 & 0.5942 & 0.3943 & 1.5273 & 3.0371 & 0.000685 \\
\hline & MAX & 0.0681 & 0.3206 & 0.9700 & 0.9409 & 4.4160 & 4.2658 & 0.001840 \\
\hline & MIN & 0.0097 & 0.1522 & 0.2812 & 0.0791 & 1.0000 & 2.2116 & 0.000135 \\
\hline & STDEV & 0.0157 & 0.0453 & 0.2103 & 0.2596 & 0.8423 & 0.4678 & 0.000466 \\
\hline & SKEW & -0.8051 & 1.3308 & 0.1725 & 0.6525 & 3.2947 & 1.1055 & 1.030664 \\
\hline \multirow[t]{5}{*}{2007} & MEAN & 0.0408 & 0.2060 & 0.6082 & 0.4108 & 1.6449 & 3.0936 & 0.000641 \\
\hline & MAX & 0.0597 & 0.3275 & 1.0000 & 1.0000 & 5.7385 & 4.3267 & 0.001151 \\
\hline & MIN & 0.0103 & 0.1343 & 0.3089 & 0.0954 & 1.0000 & 2.3462 & 0.000078 \\
\hline & STDEV & 0.0177 & 0.0606 & 0.2094 & 0.2688 & 1.1672 & 0.4661 & 0.000354 \\
\hline & SKEW & -0.8712 & 0.9883 & 0.2900 & 0.7777 & 3.5097 & 1.2621 & -0.443486 \\
\hline \multirow[t]{5}{*}{2008} & MEAN & 0.0476 & 0.1870 & 0.6421 & 0.4572 & 1.3868 & 3.1386 & 0.000563 \\
\hline & MAX & 0.0685 & 0.3180 & 1.0000 & 1.0000 & 3.2282 & 4.3570 & 0.001501 \\
\hline & MIN & 0.0100 & 0.1208 & 0.3116 & 0.0971 & 1.0000 & 2.4407 & 0.000033 \\
\hline & STDEV & 0.0176 & 0.0571 & 0.2195 & 0.2813 & 0.5884 & 0.4560 & 0.000439 \\
\hline & SKEW & -1.2470 & 0.8501 & -0.0791 & 0.3111 & 2.6812 & 1.3405 & 1.184395 \\
\hline \multirow[t]{5}{*}{2009} & MEAN & 0.0486 & 0.1932 & 0.6472 & 0.4635 & 1.2760 & 3.1798 & 0.000389 \\
\hline & MAX & 0.0654 & 0.3446 & 1.0000 & 1.0000 & 2.7245 & 4.3636 & 0.002536 \\
\hline & MIN & 0.0077 & 0.1289 & 0.3121 & 0.0974 & 1.0000 & 2.4780 & 0.000033 \\
\hline & STDEV & 0.0181 & 0.0569 & 0.2187 & 0.2822 & 0.4679 & 0.4554 & 0.000621 \\
\hline & SKEW & -1.4157 & 1.3799 & -0.0884 & 0.3014 & 2.6495 & 1.1859 & 3.331715 \\
\hline
\end{tabular}

Table 4. Correlation matrix for the model variables

\begin{tabular}{cccccccc}
\hline & RSK & CAR & HLD & HLD_SQR & FRN & LTOA & FRQ \\
\cline { 2 - 7 } CAR & 1 & & & & & & \\
HLD & -0.3924 & 1 & & & & & \\
HLD_SQR & -0.3128 & 0.3357 & 1 & & & & \\
FRN & -0.3982 & 0.3355 & -0.9804 & 1 & & & \\
LTOA & -0.4747 & -0.1834 & -0.1433 & -0.1629 & 0.5388 & 1 & \\
FRQ & -0.0943 & 0.1914 & -0.0376 & -0.0644 & -0.1183 & -0.1334 & 1 \\
\hline
\end{tabular}


The correlation coefficient between CAR and RSK that equals -0.39243 means that RSK is negatively related to the variable CAR, which indicates that the regulations which require banks to increase CAR is related negatively with bank risk taking. The correlation coefficient between the variable HLD and banks risk taking equals to -0.31283 . HLD_SQR has a correlation coefficient with bank risk taking equals -0.3421 . The correlation coefficient between bank risk taking and HLD and HLD_SQR has an interpretation that the existence of the stable shareholders in the board of directors is negatively related to the bank risk taking. The correlation coefficient between FRN and bank risk taking is -0.39829 , this means that FRN is negatively related to the bank risk taking. Regarding the control variables, LTOA \& FRQ, the correlation coefficient between LTOA and bank risk taking is -0.47477 , this relationship means that the LTOA is negatively related with bank risk taking. FRQ has a negative relationship with bank risk taking RSK, with a correlation coefficient equal to -0.09436.

The researchers tested the causality between variables using Granger Causality test with 2, 4, and 6 lags because of the data is annual, The Granger Causality test results shows, using (2 Lags), that there is a two-way significant relationship between RSK and LTOA. When using a (4 Lags), the Two-Way significant relationship between the variables RSK and FRQ is found, and it is found that there is a One-Way relationship between CAR and RSK, variable CAR is Granger Cause the RSK. Using (6 Lags), the researcher found a One-Way relationship between RSK and FRN, which means that RSK is granger cause the FRN. It is important to know that the notion of Granger Causality does not imply true Causality, it only implies forecasting ability.

Table 5. Pairwise Granger Causality Tests for 2, 4, and 6 Lags

\begin{tabular}{|c|c|c|c|c|c|c|}
\hline \multirow[t]{2}{*}{ Causality Direction } & \multicolumn{2}{|c|}{2 Lags } & \multicolumn{2}{|c|}{4 Lags } & \multicolumn{2}{|c|}{6 Lags } \\
\hline & F-Statistic & P-Value & F-Statistic & P-Value & F-Statistic & P-Value \\
\hline $\mathrm{CAR} \rightarrow \mathrm{RSK}$ & 1.93729 & 0.14823 & 2.32849 & $0.06158 * *$ & 3.2577 & $0.00755 *$ \\
\hline $\mathrm{RSK} \rightarrow \mathrm{CAR}$ & 0.19331 & 0.82446 & 1.58247 & 0.18518 & 1.23119 & 0.30276 \\
\hline $\mathrm{HLD} \rightarrow \mathrm{RSK}$ & 0.74696 & 0.47583 & 0.82883 & 0.51004 & 0.76569 & 0.59969 \\
\hline $\mathrm{RSK} \rightarrow \mathrm{HLD}$ & 0.85665 & 0.42696 & 0.69652 & 0.59619 & 0.75411 & 0.60858 \\
\hline HLD_SQR $\rightarrow$ RSK & 0.47972 & 0.62005 & 0.70139 & 0.59288 & 0.50614 & 0.8014 \\
\hline RSK $\rightarrow$ HLD_SQR & 0.97167 & 0.38118 & 0.98498 & 0.41956 & 0.33012 & 0.91861 \\
\hline $\mathrm{FRN} \rightarrow \mathrm{RSK}$ & 2.08778 & 0.1281 & 0.74859 & 0.56133 & 0.5338 & 0.7805 \\
\hline $\mathrm{RSK} \rightarrow \mathrm{FRN}$ & 0.59812 & 0.55135 & 0.16885 & 0.95377 & 1.9149 & $0.09241 * *$ \\
\hline $\mathrm{LTOA} \rightarrow \mathrm{RSK}$ & 3.86769 & 0.02335* & 0.93969 & 0.44448 & 0.69151 & 0.65725 \\
\hline $\mathrm{RSK} \rightarrow \mathrm{LTOA}$ & 4.53802 & $0.01244 *$ & 3.02568 & $0.02134 *$ & 0.4817 & 0.81948 \\
\hline $\mathrm{FRQ} \rightarrow \mathrm{RSK}$ & 0.63189 & 0.53321 & 3.11985 & $0.01848 *$ & 1.72975 & 0.129 \\
\hline $\mathrm{RSK} \rightarrow \mathrm{FRQ}$ & 2.15991 & 0.11946 & 2.41997 & $0.05364 * *$ & 2.47616 & $0.03273 *$ \\
\hline
\end{tabular}

* Significant at the level 0.1

** Significant at the level 0.05

Variance Decomposition indicates the amount of information each variable contributes to the other variables in the regression. Variance decomposition determines how much of the forecast error variance of each of the variables can be explained by exogenous shocks to the other variables. Table (6) shows the results of variance decomposition for Bank Risk Taking (RSK). For the variable RSK, the error in variance decomposition is $100 \%$ for the first period due to the variable itself.

The error in prediction of variance for Bank Risk Taking (RSK) after 4 time periods is $2.793798,1.960218,2.133611$, 1.845942, 1.663918 and 1.497111, due to the changes in Capital Adequacy Ratio, Stable Shareholders, Squared Values of Stable Shareholders, Franchise Value, Log of Total Assets, and frequency, respectively. The table shows that these ratios are equal to 2.297905, 2.297905, 5.916186, 3.170305, 2.157727 and 6.353181 after ten time periods. Table 7 shows variance decomposition after reordering the variables. Similarity of data after re-ordering it is an indicator of the strong relationship between the variables in the study period. 
Table 6. Variance decomposition

\begin{tabular}{ccccccccc}
\hline Period & S.E. & RSK & CAR & HLD & HLD_SQR & FRA & LTOA & FRE \\
\hline 1 & 0.01111 & 100.0000 & 0.00000 & 0.00000 & 0.00000 & 0.00000 & 0.00000 & 0.00000 \\
2 & 0.01235 & 96.24914 & 2.82672 & 0.25692 & 0.03139 & 0.10950 & 0.52552 & 0.00081 \\
3 & 0.01285 & 91.92970 & 2.92468 & 0.87325 & 0.97230 & 0.94442 & 1.42556 & 0.93010 \\
4 & 0.01322 & 88.10540 & 2.79380 & 1.96022 & 2.13361 & 1.84594 & 1.66392 & 1.49711 \\
5 & 0.01353 & 84.73115 & 2.69257 & 3.00294 & 3.10936 & 2.47606 & 1.78801 & 2.19991 \\
6 & 0.01382 & 81.55743 & 2.58990 & 4.13220 & 3.93264 & 2.84572 & 1.90658 & 3.03553 \\
7 & 0.01409 & 78.66545 & 2.49573 & 5.29106 & 4.61144 & 3.04378 & 1.99591 & 3.89662 \\
8 & 0.01434 & 76.05069 & 2.41506 & 6.42812 & 5.15087 & 3.13724 & 2.06357 & 4.75444 \\
9 & 0.01457 & 73.68122 & 2.34891 & 7.52356 & 5.57727 & 3.17029 & 2.11710 & 5.58165 \\
10 & 0.01479 & 71.54124 & 2.29790 & 2.29791 & 5.91619 & 3.17031 & 2.15773 & 6.35318 \\
\hline
\end{tabular}

Cholesky Ordering: RSK CAR HLD HLD_SQR FRA LTOA FRE

Table 7. Variance decomposition after re-ordering the data

\begin{tabular}{ccccccccc}
\hline Period & S.E. & RSK & FRE & LTOA & FRA & HLD_SQR & HLD & CAR \\
\hline 1 & 0.01111 & 100.0000 & 0.00000 & 0.00000 & 0.00000 & 0.00000 & 0.00000 & 0.00000 \\
2 & 0.01235 & 96.24914 & 0.00831 & 0.00706 & 0.07056 & 0.36783 & 0.35351 & 2.94359 \\
3 & 0.01285 & 91.92970 & 0.55515 & 0.48569 & 0.95376 & 1.78368 & 0.70098 & 3.59104 \\
4 & 0.01322 & 88.10540 & 0.80351 & 0.64589 & 2.00091 & 3.62226 & 1.24510 & 3.57695 \\
5 & 0.01353 & 84.73115 & 1.16271 & 0.71514 & 2.78153 & 5.35909 & 1.70240 & 3.54799 \\
6 & 0.01382 & 81.55743 & 1.63882 & 0.78106 & 3.29302 & 7.18815 & 2.06466 & 3.47686 \\
7 & 0.01409 & 78.66545 & 2.15405 & 0.82530 & 3.61366 & 9.00998 & 2.34144 & 3.39012 \\
8 & 0.01434 & 76.05069 & 2.68486 & 0.84764 & 3.80720 & 10.76121 & 2.53510 & 3.31331 \\
9 & 0.01457 & 73.68122 & 3.20743 & 0.85526 & 3.92052 & 12.42031 & 2.66415 & 3.25112 \\
10 & 0.01479 & 71.54124 & 3.69958 & 0.85250 & 3.98507 & 13.97082 & 2.74737 & 3.20339 \\
\hline
\end{tabular}

Cholesky Ordering: RSK FRE LTOA FRA HLD_SQR HLD CAR

\section{Regression Analysis}

Regression analysis is used to understand how typical values of the dependent variable changes when any of the independent variables is varied. In general, regression analysis estimates the conditional expectation of dependent variables, given the independent variables.

Table 8. Multiple regression analysis output

\begin{tabular}{cc}
\hline Variable & RSK \\
\hline CAR & -0.0931 \\
& $(-6.6152)^{*}$ \\
HLD & 0.0787 \\
& $(3.2367)^{*}$ \\
HLD_SQR & -0.0951 \\
& $(-4.5909)^{*}$ \\
FRN & -0.0013 \\
& $(-3.5010)^{*}$ \\
LTOA & -0.0220 \\
& $(-8.6995)^{*}$ \\
FRQ & -4.1002 \\
\hline
\end{tabular}




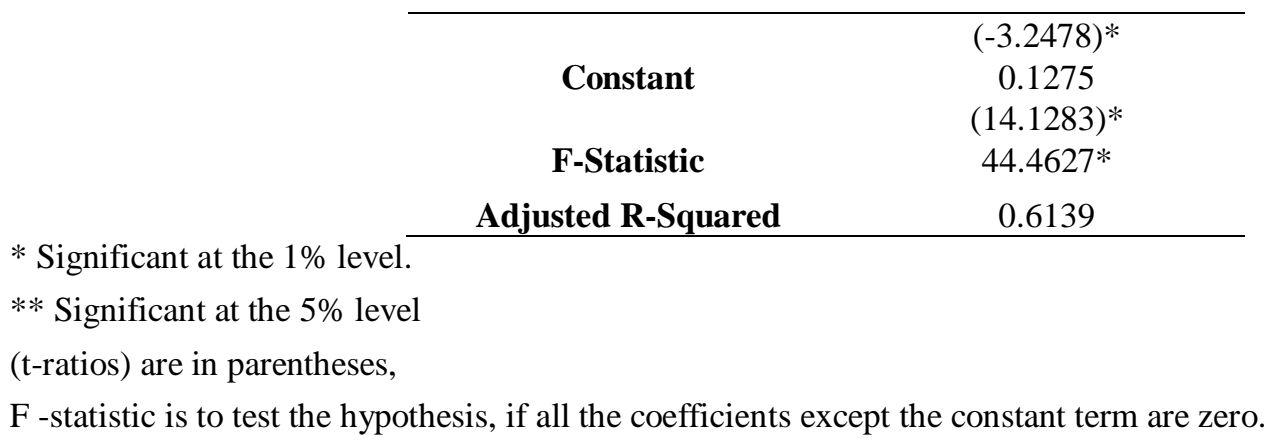

According to the results of the regression analysis, the research model has become:

$$
\text { RSK }=0.127-0.093 \text { CAR }+0.079 H L D-0.095 \text { HLD_SQR }-0.001 \text { FRN }-0.022 \text { LTOA }-4.100 \text { FRQ }
$$

The -0.093 coefficient of CAR means that an increase by $100 \%$ in CAR will decrease the value if RSK by 0.093 . All variables have a negative effect on bank risk taking except the Stable Shareholders HLD; the coefficient of FRQ variable is higher than the coefficients of the other variables reflect the small values of FRQ. The F-statistics is used for testing the joint significance of all independent variables CAR, HLD, HLD_SQR, FRA, LTOA, and FRQ on bank risk taking. The null hypothesis is that there is no significant effect of all independent variables jointly on bank risk taking; according to the F-Calculated value and the P-value we rejected the null hypothesis because of that the absolute F-Calculated that equal 44.4627 is greater than the F-Tabulated, and the P-value is equal 0.000 which is less than $1 \%$. The adjusted R-Squared value represents the explanatory power of the independent variables about the dependent variable (Bank Risk Taking), the 0.6139 R-Squared means that the independent variables CAR, HLD, HLD_SQR, FRA, LTOA, and FRQ explain 0.6139 of the independent variable bank risk taking RSK.

\section{First Hypothesis}

H0: Capital adequacy ratio (CAR) is not negatively and not significantly affects the level of bank risk taking, as shown in table the null hypothesis is rejected and the alternative hypothesis is accepted, which indicates that capital adequacy ratio (CAR) is negatively and significantly affects the level of bank risk taking. The result of the first hypothesis regarding the negative effect of capital adequacy ratio on bank risk taking is favorable for (Konishi et al., 2004), (Zong-yi et al., 2008), and (Leonard et al., 1998). All of these studies proved that there is a significant negative effect of capital adequacy ratio on bank risk taking. On the other hand, (Brooks et al., 1997), (Blum, 1999), and (Lin et al., 2005) found that there is a positive significant effect of capital adequacy ratio on bank risk taking. In addition, (Laeven et al., 2006) state that Capital Requirements and Official Supervisory don't affect bank risk taking.

\section{Second Hypothesis}

H0: Ownership by stable shareholders (HLD_SQR) is not negatively and not significantly affects the level of bank risk taking. As shown in the regression results the minus coefficient is an indicator of the negative effect, so the null hypothesis is rejected and the alternative hypothesis is accepted, which argues that ownership by stable shareholders (HLD_SQR) is negatively and significantly affects the level of bank risk taking. We conclude from the result that there is a significant positive effect of HLD on bank risk taking. The researcher used the HLD_SQR variable to study the linearity between stable shareholders and bank risk taking. The above results show that both variables; HLD and HLD_SQR, have a significant effect on bank risk taking, but in opposite directions. The found negative significant effect of Squared Values of Stable Shareholders HLD_SQR on bank risk taking is favorable for (Konishi et al., 2004) and (Iannotta et al., 2007). On the other hand, the positive significant effect of HLD on bank risk taking is favorable for (Houston et al., 2010), and (Pathan, 2009).

Many researchers stated that the effect of stable shareholders on bank risk taking might be positive or negative. The negative effect of stable shareholders on bank risk taking appears when the bank managers become more risk averse than investors, the positive effect of stable shareholders on bank risk taking occurs when a bank manager's preference is aligned with the interest of shareholders of the bank.

\section{Third Hypothesis}

H0: Franchise Value (FRN) is not negatively and not significantly affects the level of bank risk taking. According to the regression results, the null hypothesis is rejected and the alternative hypothesis is accepted, which argues that Franchise Value (FRN) is negatively and significantly affects the level of bank risk taking. For the above hypothesis, the researcher found a negative effect of franchise value on bank risk taking, which is favorable for (Konishi et al., 2004), (Jiménez et al., 2007), (Weisbrod et al., 1992) and (Demsetz et al., 1996). 


\section{Log of Total Assets and Frequency}

The researcher added the log of Total Assets as a control variable in order to capture the size effect between banks in the regression model. The regression results indicate that LTOA has a negative significant effect on bank risk taking. The Frequency variable (FRQ) was added to the model as a control variable in order to capture the effect of stock trade of each bank. FRQ is defined as the average daily volume of shares divided by the total number of outstanding shares. The results prove that the FRQ has a negative significant effect on bank risk taking.

\section{Conclusion}

The main contribution of this study is that the researchers developed a model that contains many variables tested in worldwide studies in order to find the factors that affecting bank risk taking in Jordan, This study has tested the effect of Capital Adequacy Ratio (CAR), Stable Shareholders (HLD), the Squared Values of Stable Shareholders (HLD_SQR), and Franchise Value (FRN) on Bank Risk Taking (RSK) by using two control variables the log of total assets (LTOA) and frequency (FRQ), This study has empirically examined the Jordanian banks' data for the period 1999 to 2009 and has found that CAR, HLD_SQR, and FRA negatively affect bank risk taking and HLD positively affect bank risk taking which is a contribution to the prepared studies in this field.

Bank Risk Taking (RSK) was found to be adversely affected by Capital Adequacy Ratio (CAR), which means that increasing capital adequacy ratio will reduce bank risk taking. The Franchise value (FRN) has a negative effect on bank risk taking (RSK), meaning that as franchise value increases, bank risk taking will decrease. The Stable Shareholder (HLD) variable has a significant positive effect on Bank Risk Taking (RSK). The squared value of Stable Shareholders (HLD_SQR) has a significant negative effect on Bank Risk Taking (RSK).

The importance of the banking sector as a repository of customers' deposits and loan provider for businesses and individuals, in addition to the lack of bank risk studies in Jordan and in the Middle East make any study focusing on bank risk of high importance, it provides a first insight of the problem and lays down a foundation for future studies.

\section{References}

Bank for International Settlements. (2004). Implementation of Basel II: Practical Considerations. Press \& Communications CH-4002 Basel, Switzerland.

Bank for International Settlements. (2006). International convergence of capital measurement and capital standards, A Revised Framework Comprehensive Version. Press \& Communications CH-4002 Basel, Switzerland.

Blum, J. (1999). Do capital adequacy requirements reduce risks in banking?. Journal of Banking \& Finance, 23, 755-771. https://doi.org/10.1016/S0378-4266(98)00113-7

Brooks, R., Faff, R., \& Ho, Y. (1997). A new test of the relationship between regulatory change in financial markets and the stability of beta risk of depository institutions. Journal of Banking \& Finance, 21, 197-219.

Buch, C., \& DeLong, G. (2008). Do weak supervisory systems encourage bank risk-taking?. Journal of Financial Stability, 4, 23-39. https://doi.org/10.1016/j.jfs.2007.12.002

Cebenoyan, S., \& Strahan, P. (2004). Risk management, capital structure and lending at banks. Journal of Banking \& Finance, 28, 19-43. https://doi.org/10.1016/S0378-4266(02)00391-6

Delis, D., \& Kouretas, G. (2010). Interest rates and bank risk-taking. Paper No, 20132. Retrieved from http://mpra.ub.uni-muenchen.de/20132/ MPRA

Demsetz, R., Saidenberg, M., \& Strahan, P. (1996). Banks with something to lose: the disciplinary role of franchise value. Frbny Economic Policy Review. https://doi.org/10.2139/ssrn.1028769

Godlewski, C. (2005). Bank capital and credit risk taking in emerging market economies. Journal of Banking Regulation, 6, 128-145. https://doi.org/10.1057/palgrave.jbr.2340187

Hasan, M. (2002). The significance of Basel 1 and Basel 2 for the future of the banking industry with special emphasis on credit information, Presented in the Credit Alliance/ Information Alliance Regional Meeting. Amman, Central Bank of Jordan. Retrieved from http://www.cbj.gov.jo

Houston, J., Lin, C., Lin, P., \& Ma, Y. (2010). Creditor rights, information sharing, and bank risk taking. Journal of Financial Economics. https://doi.org/10.1016/j.jfineco.2010.02.008

Iannotta, G., Nocera, G., \& Sironi, A. (2007). Ownership structure, risk and performance in the European banking industry. Journal of Banking \& Finance, 31, 2127-2149.

Jeitschko, T., \& Jeung, S. (2005). Incentives for risk-taking in banking a unified approach. Journal of Banking \& Finance, 29, 759-777. https://doi.org/10.1016/S0378-4266(04)00057-3 
Jiménez, G., Lopez, J., \& Saurina, J. (2007). How does competition impact bank risk-taking?. Working Paper (23). https://doi.org/10.24148/wp2007-23

Jokipii, T., \& Milne, A. (2010). Bank capital buffer and risk adjustment decisions. Journal of Financial Stability, 148.

Jonghe, O., \& Vennet, R. (2008). Competition versus efficiency: what drives franchise values in european banking?. Journal of Banking \& Finance, 32, 1820-1835. https://doi.org/10.1016/j.jbankfin.2007.12.009

Kim, D., \& Santomero, A. (1988). Risk in banking and capital regulation. The Journal of Finance, 43, 1219-1233.

Konishi, M., \& Yasuda, Y. (2004). Factors affecting bank risk taking: evidence from Japan. Journal of Banking \& Finance, 28, 215-232. https://doi.org/10.1016/S0378-4266(02)00405-3

Laeven, L., \& Levine, R. (2006). Corporate governance, regulation, and bank risk taking. Department of Economics, Brown University.

Laeven, L., \& Levine, R. (2009). Bank governance, regulation and risk taking. Journal of Financial Economics, 93, 259-275. https://doi.org/10.1016/j.jfineco.2008.09.003

Leonard, P., \& Biswas, R. (1998). The impact of regulatory changes on the risk-taking behavior of state chartered savings banks. Journal of Financial Services Research, 13(1), 37-69. https://doi.org/10.1023/A:1007954410976

Lepetit, L., Nys, E., Rous, P., \& Tarazi, A. (2008). Bank income structure and risk: An empirical analysis of European banks. Journal of Banking \& Finance, 32, 1452-1467. https://doi.org/10.1016/j.jbankfin.2007.12.002

Lin, S., Penm, J., Gong, S., \& Chang, C. (2005). Risk based capital adequacy in assessing on insolvency-risk and financial performances in Taiwan's banking industry. Research in International Business and Finance, 19, 111-153. https://doi.org/10.1016/j.ribaf.2004.10.006

Lindquist, K. (2004). Banks' buffer capital: how important is risk. Journal of International Money and Finance, 23, 493-513. https://doi.org/10.1016/j.jimonfin.2004.01.006

Marco, T., \& Fern'andez, M. (2008). Risk taking behavior and ownership in the banking industry: the Spanish evidence. Journal of Economics and Business, 60, 332-354. https://doi.org/10.1016/j.jeconbus.2007.04.008

Marcus, A. J. (1984). Deregulation and bank financial policy. Journal of Banking \& Finance, 8(4), 557-565.

Murphy, N., \& Salandro, D. (1997). Form of ownership and risk taking in banking some evidence from massachusetts saving banks. Journal of Economics and Finance, 21(3), 19-28. https://doi.org/10.1007/BF02929035

Niinimaki, J. (2003). The effects of competition on banks' risk taking. Journal of Economics, 81(3), 199-222. https://doi.org/10.1007/s00712-003-0027-9

Pathan, S. (2009). Strong boards, CEO power and bank risk-taking. Journal of Banking \& Finance, 33, 1340-1350.

Ren, Y., \& Schmit, J. (2006). Franchise value, competition and insurer risk-taking. University of Wisconsin-Madison. Retrieved from www.aria.org/meetings/2006papers/RenSchmit.pdf

Repullo, R. (2004). Capital requirements, market power, and risk-taking in banking. Journal of Financial Intermediation, 13, 156-182. https://doi.org/10.1016/j.jfi.2003.08.005

Sullivan, R., \& Spong, K. (2007). Manager Wealth concentration, ownership structure, and risk in commercial banks. Journal of Financial Intermediation, 16, 229-248. https://doi.org/10.1016/j.jfi.2006.12.001

Weisbrod, S., Lee, H., \& Suarez, L. (1992). Bank risk and the declining franchise value of the banking systems in the united states and japan. Master Files Room C-525. IMF International Monetary Fund Working Paper, $\mathrm{WP} / 92 / 45$.

Zhang, Z-Y., Wu, J., \& Liu, Q-F. (2008). Impacts of capital adequacy regulation on risk-taking behaviors of banking. Systems Engineering - Theory \& Practice, 28(8), 183-189. https://doi.org/10.1016/S1874-8651(09)60035-1

\section{Copyrights}

Copyright for this article is retained by the author(s), with first publication rights granted to the journal.

This is an open-access article distributed under the terms and conditions of the Creative Commons Attribution license (http://creativecommons.org/licenses/by/4.0/). 